\title{
Negotiating the Nation: Knowledge and Meaning at Vaucluse House in its First Curatorial Period
}

\author{
SUSAN MCCLEAN
}

\footnotetext{
Taucluse House museum was inaugurated during World War I to educate visitors about the work of nineteenth-century parliamentarian William Charles Wentworth, in particular his role in the installation of British institutions in New South Wales, including his writing of the first Constitution and the foundation of the responsible government, which underpinned twentieth-century Australian democracy. It has been in the charge of three agencies during its existence as a museum which broadly correspond to three curatorial approaches.

Others have documented some of the problems and changes at the house. ${ }^{1}$ This article, however, uses museum theory concerning the
} 
character of the modern disciplinary museum, as well as the tendency of that institution to shape knowledge, to explain the experience offered to audiences at Vaucluse House over the museum's first curatorial period. It argues that, in the context of war and an official need to press empire nationalist identity, particular curatorial practices and museological assumptions shaped the themes available and assumed certain audience responses. In the absence of any contemporary methods for assessing museum work in detail, the decision to install a major thematic display of constitutional history intermingled with a house museum interpretation produced mixed messages. Unexpected new evidence and ingenuous curatorial expansion of the rooms available for inspection soon produced unintended consequences. In a changing historical and cultural context, the major theme and rationale of the museum began to be undermined and the house museum interpretation began to dominate. It was this focus which was finally and belatedly endorsed by the museum Trustees in the mid 1950s.

\section{THE POLITICS OF THE MUSEUM}

The Royal Commission into the Improvement of the City of Sydney and its Suburbs had in 1909 recommended the acquisition of lands for public recreation and foreshore access. The government purchased and gazetted the old Vaucluse estate in $1911 .^{2}$ The role of the government-appointed Vaucluse Park Trust (VPT) was to manage, on behalf of the government, the land as a public park for the health and recreation of city populations whose neighborhoods suffered overcrowding and lacked public amenities. The Trustees were, initially, men of social progressive persuasion, the backbone of the old Liberal Reform Party, and its later more conservative political manifestations, the National Party and the United Australia Party. Like many middle-class educated men, they offered themselves voluntarily, out of sense of service for the public good.

At first the old house had not seemed significant to the Trustees. From their earliest days in charge, however, visitors sought admission to the museum, with women's groups among the first. ${ }^{3}$ The VPT had little knowledge of Australian history. In response to public interest they began to build up a record of the history of ownership of the property. In May 1915, early in the war and soon after the news of the Gallipoli campaign had reached Australia, the 
Australian Historical Society's (RAHS) ${ }^{4}$ research officer, Captain James Watson, led a visit to Vaucluse House. RAHS members were engaged in researching, writing and promoting the national story. They informed the Trustees that Wentworth's activities were significant for the nation. The largely middle-class RAHS Council and membership were largely aligned with the empire nationalism of mainstream politics and culture. This was underpinned by economic ties with Britain through major industries, especially the pastoral and other rural industries and through preferential tariffs for British manufactures. ${ }^{5}$ The RAHS was committed to a history of Australia as a British colony in the past, and a contemporary Australian nation, reserved for the white race and the British Empire. ${ }^{6}$ Benedict Anderson notes that official cultures in colonial places often imagined their nationalist communities and cultures as linked to the metropolitan centre, even after independence. He suggested that these groups especially found museums useful for promoting their vision of the nation. ${ }^{7}$

Immediately the Trustees began transforming Wentworth's home into a museum. This they did with the support and expertise of the RAHS. So well-aligned were the values of the two organisations, that soon after World War I they considered a formal merger to create a museum of Australian history at Vaucluse House. ${ }^{8}$ When this did not eventuate, the presence of RAHS members at Vaucluse became less regular. Empire loyalist biographies written about two owners of the house - Sir Henry Brown Hayes and William Charles Wentworth - by prominent members of the RAHS - Charles Bertie and Karl Cramp respectively - remained in use, however, and were for sale at the museum.

The RAHS, whose membership included a number of academic historians from Sydney University and the Teacher's College, as well as a more amateur cohort, thus offered a disciplinary basis for the museum as well as organisational assistance. In the absence of any Australian history courses at the university, the RAHS provided a focus for research and publication in Australian history in New South Wales and beyond through its journal and forums. Leading academics of the society promoted the scientific methods of von Ranke, seeing history as the record of the work of public men, or 'great men', often for the state or nation. History was understood as an objective science, its knowledge based on verifiable facts and the particular contexts from which those facts emerged. ${ }^{9}$ The presence of 
amateur members, however, ensured that its practice was in fact as much antiquarian as historical. ${ }^{10}$ Following co-operation with the RAHS, the Vaucluse Park Trustees were soon quite clear that they were creating at Vaucluse House a museum where an 'Australian History and Ideal ${ }^{11}$ could inspire visitors with loyalty to a middleclass, empire-based vision of Australia.

Why might the Trustees have responded so speedily? In the context of war supported by empire nationalists, when accounts of the involvement of Australian troops at Gallipoli were circulating widely, the museum provided both an opportunity to encourage patriotism through pride in Australia's history and a role for history articulated by the school educators, such as Historian Karl Cramp of the RAHS. ${ }^{12}$ A museum at Vaucluse could be a place where a nation imagined as an English entity could be installed. A house whose owners had strong English connections and were associated with Anglican religion might provide visual rhetoric to counter the opposing, local nationalist vision of Australian identity. This view, developed in the 1890s and celebrated in verse and story by Henry Lawson and other Bulletin writers, was largely held by working men and women whose sympathies were inclined to be Irish and catholic. Many expressed strong egalitarian views of national politics and culture and fiercely opposed the war. ${ }^{13}$ These opposing nationalist identities were in great tension during the war when bitter class conflict split the nation. Wentworth had been a young explorer, but had, moreover, fought vigorously for the installation of British institutions in New South Wales including trial by jury and freedom of the press. His 1855 Constitution of New South Wales. His constitution for New South Wales, Karl Cramp argued, became a model, albeit modified, for the federal constitution some fifty years later, implying national significance for the museum. ${ }^{14}$ In the public service offered by Wentworth's work, the Trustees found a theme which might inspire national pride and encourage the unity, stability and national harmony. Immediately they began a long-lasting program of installing nationalist symbols. They introduced Australian native animals and plants into the garden and a prominent Union Jack and Australian flag were placed side by side at the front of the house. ${ }^{15}$

The Trustees initially permitted entry on request to the house, seeing it as little more than a public asset on the land they 
administered as a major recreational parkland for the people. ${ }^{16}$ Soon, letters to the press and to the VPT began to appear, as some among the wider populace began to articulate the sacred and national values that they attached to the place. In 1913, a letter to the Sydney Morning Herald pressed the government to consider undertaking the renovation of Vaucluse House as 'a libation to the Gods' ${ }^{17}$ Similar expressions evoking pilgrimage to a shrine continued for some three decades. ${ }^{18}$ Carol Duncan and Allan Wallach have undertaken visual and spatial analyses at the Louvre, drawing attention to the association of museums with religious language and ritual behaviour. ${ }^{19}$ Visitors to Vaucluse, like those at the Louvre, would also move together through the museum along a formal path determined both by the architecture and the exhibits, stopping at key stages to reverently pay respect to the building and the exhibits, performing a ritual procession through the building. ${ }^{20}$

Museum theorist Eilean Hooper-Greenhill using a Foucaudian framework has shown that the changing forms and functions of museums over the long durée has meant a shift in the knowledge transmitted to the audiences of the museum. Indeed, she argues, like its fore-runners, the modern, disciplinary museum, which emerged at the Louvre following the French revolution, shaped knowledge made available to audiences. ${ }^{21}$ Museums based on the Louvre, previously a royal palace, were now characterised by the contradictory aims of maintaining an elite temple of the arts while simultaneously bearing responsibility for educating the wider populace. New professional practices encouraged comprehensive collections, a national framework and a systematic approach to collecting, sorting, documenting, conserving and displaying collections. In the context of the liberation politics of the French Revolution, the ideal of educating the people by exposing them to the civilising influence of collections of fine paintings and artefacts produced the practice of allowing people to walk freely through the galleries. At the same time, the museum provided attendants whose responsibility it was to undertake surveillance on visitors and to restrain their behaviour for the security of the collections. ${ }^{22}$

What sort of museum did the Vaucluse Park Trust envisage? Their aim was that the house be 'preserved for the nation'. They intended 'to replace as far as possible any of the original furniture and effects, restore the house and make it a museum for Australian subjects and keep [it] in good order as a tribute to the memory of 
Wentworth.' Consistent with RAHS policy, this was to be a white history. Race considerations aside, here we see other conflicting aim: that of a house museum - a domestic space - celebrating Wentworth; and that of a comprehensive Australian history museum. Both ideas were officially sustained and later it was decided that other furnishings 'of the period' would also need to be collected. ${ }^{23}$ These aims which affected the content of the collections and the displays, in concert with the museum methods of the day, impacted both on knowledge and also on cultural meanings available at the site. These meanings, based as they were on a modernist approach, were essentially rigid and narrow.

The fabric of the old home was an important element of the museum. Vaucluse House's rambling architecture was unremarkable as the private home of an eccentric, if eminent, parliamentarian and his family. Indeed it had existed in this irregular form since the 1850s and was the only configuration that anyone, including the surviving Wentworths, could actually remember. But its form did not have enough style and finish to impress locals and foreigners with the glory of the nation. In 1917, when undertaking early maintenance, the VPT upgraded the façade, adding very visible, aesthetic elements to the historic monument in the form of two new turreted towers and some extra parapets at the eastern end of the house. ${ }^{24}$ While the gothic embellishments heightened the British ambience of the house, the newly created symmetry and regular repeating decorative elements offered an iconographic rhetoric of stability, balance and order, similar to neo-classicism. ${ }^{25}$ Tony Bennet notes that European princely collections and the buildings which housed them had, in the past, been understood as a means of making visible, and magnifying, the power of the monarch. ${ }^{26}$ Vaucluse's new elements added a certain grandeur and presence to the house, magnifying to visitors the prestige of the museum as well as that of the state which had acquired it.

Increasing numbers of visitors came to Vaucluse especially in spring - 'the Wisteria Season' - when the verandas were swathed in swags of luxuriant, scented, mauve florets. In 1926 entry fees were first levied after the house was re-opened following the much-needed refurbishment of the ground floor of the House. Funds were needed to repay the government-guaranteed loan, which covered the cost of the work. ${ }^{27}$ Now accountable for government-linked funding for the 
house, the Trustees recorded visitors. Huge numbers were now attracted to Vaucluse House - between 32,000 and 35,000 annually from 1928-33, peaking at 40,000 from $1926-1930 .{ }^{28}$ This compares favourably with today's annual average of 32,500 for the period 20002007. Apart from recording the numbers of children, no detailed breakdown is available. Museum audiences were considered an 'abstract mass, unitary and presumed classless' ${ }^{29}$

A tour of the exhibition inside was, from the beginning, the main attraction. Visitors were marshalled at the purported front door. No obvious pathway existed as it did in the layout of a grand palace, so the liberal ideal of walking freely through the museum was abandoned and guided tours instigated. ${ }^{30}$ Nevertheless the early tours at Vaucluse did offer a range of visitors the opportunity to mingle with other citizens: poor, rich, young, old, city, country, women, men, local or foreigner. Tony Bennett shows how museums were also charged with teaching 'proper' behaviour to those ignorant of it. As public liberal institutions, museums were invested with the educational role of providing a space for the free mixing of the classes, places in which working-class visitors would feel constrained to abandon the 'rowdy' customs of places of popular assembly under pain of exclusion and learn to self-regulate, modelling their physical behaviour on the bourgeois norm displayed by middle-class visitors. ${ }^{31}$ After fees were proposed at Vaucluse in $1926,{ }^{32}$ fewer working people would have been in a position to attend the museum, especially with unemployment beginning to rise in the late 1920s. Together the changes probably sharpened the middle-class and somewhat authoritarian character of the tours.

The Guide's commentary was short. Educational principles for museums dictated that the major time in the museum was to be spent looking. The images and artefacts were systematically labelled with cards stating what were understood by the Trustees as essential facts - their name or title, their date and maker (if known) and their donor. At Vaucluse, their function or context was occasionally noted. These were museum labels more suited to communicating information to art-collectors than communicating historical messages. Visitors moving at a steady walk were meant to look at the object, complete with its kernel of essential knowledge, and understand. All other information was assumed to be known by audiences from school education or their general knowledge..$^{33}$ If more was needed, the 
biographies of owners, Sir Henry Brown-Hayes and W.C. Wentworth were offered for sale.

The tour script used between 1918 and 1928 informed people at the entrance of Vaucluse House's significance for the nation in didactic fashion emphasizing Wentworth's associations. It was 'one of the oldest... and undoubtedly the most historic house in Australia.' It explained that 'Wentworth fought and obtained for New South Wales the rights and liberties which we today enjoy and, in the Constitution Room which I will show you later the Constitution was drafted. ${ }^{\prime 34}$

Before visitors were admitted, they were therefore alerted that this space was different from the leisure grounds outside. Whatever their wishes, they were not here for fun but for learning. The museum was attached to a body of knowledge associated with monumental, even official history, displaying Australia's credentials as a civilized nation.

No formal, detailed, curatorial policy of the Trustees and their advisers from the RAHS has been found. But the history of W.C. Wentworth and his work, especially that which produced the NSW Constitution, were expressed to great extent through three exhibitionary modes: firstly the nature and meaning of the tour, secondly the exhibitions in three themed rooms scattered through the house and thirdly the reinstatement of the house museum. I will deal with these in the order that visitors met them on a tour, integrating the insights of museum history and theory with the curatorial practices utilised at Vaucluse.

Having passed through the entrance to the house, the tour was poised to enter the Reception Room and then move through the Drawing Room and then into the Small Lobby. The doors to the formal Dining Room ${ }^{35}$ and what the Trustees called 'the Ladies' Morning Room' gave off from here. Visitors then moved through the long Hall at the back, across the courtyard to the Family Dining Room and finally into the Study or Library (see Figure 1). This pathway was immensely meaningful to the Trustees for it constituted the route, which the Trustees believed Wentworth had often trod, from his front door through his house to his Library. Visitors were therefore encouraged to ritually tread in what the Trustees romantically imagined were the footsteps of the Great Man, as he 
entered his home and walked through to his inner sanctum, the site of his work, his 'library.'

\section{THE ANCESTORS OF THE NATION}

A gallery of sixteen oak-framed historic portraits, clearly a themed exhibit, greeted visitors immediately inside the front door in a space

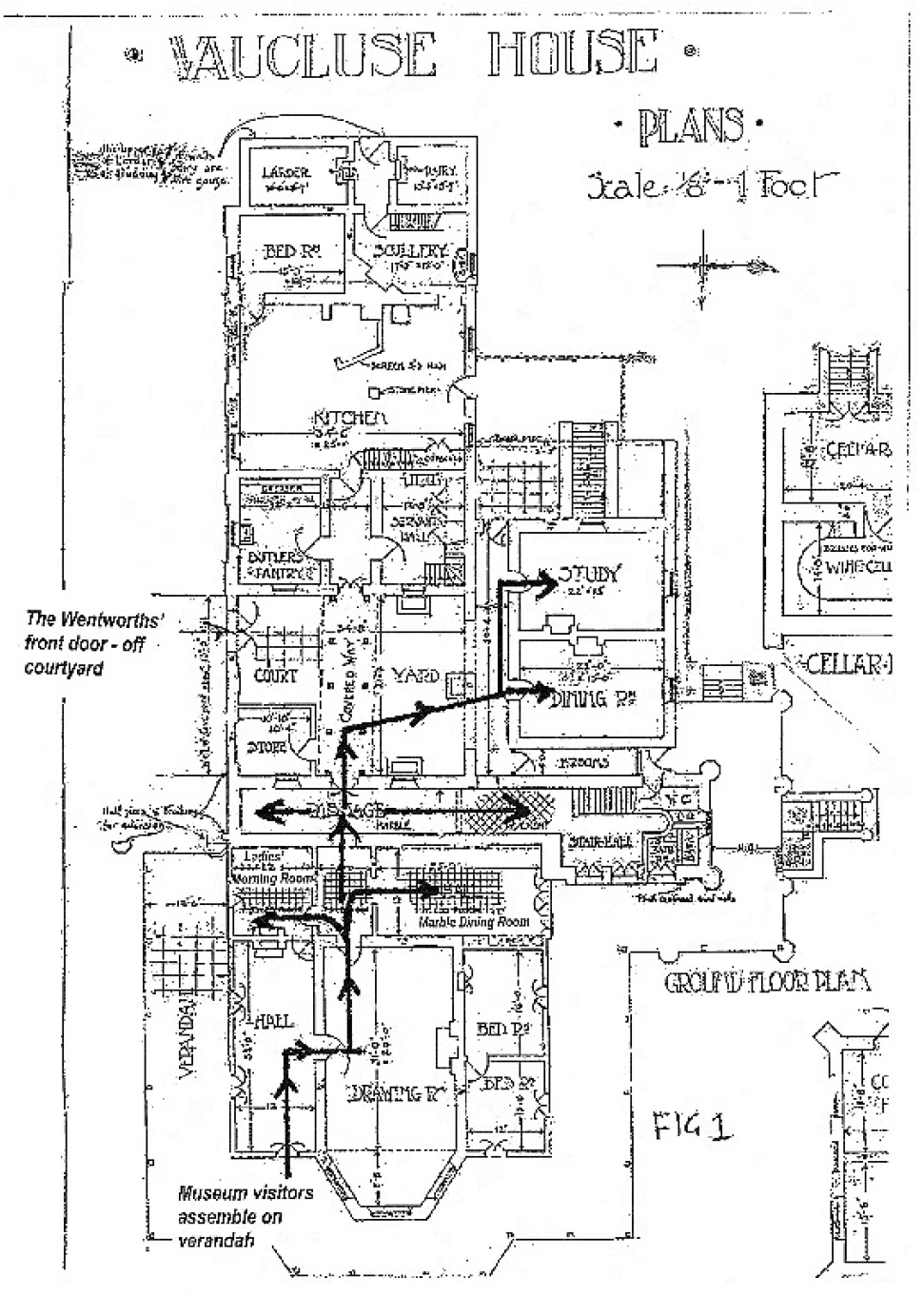

Figure 1: Vaucluse House Plans (detail) 1910, re-issued 1920

Ground floor of Vaucluse House, amended, 2007 to show the proposed route of early tour (Neilsen-Vaucluse Park Records, Vaucluse House Collection) 
the VPT called the Reception Room. ${ }^{36}$ Thomas Carlyle's nineteenthcentury writing was still influential in NSW history education circles due to the considerable influence of Professor George Arnold Wood and Teacher's College historian, RAHS Secretary, Karl Cramp. Carlyle had argued that the value of a sincere portrait was that it put the visitor in direct contact, despite the intervening years, with the sitter. The purpose of national history was not solely to discover what had happened. It supposedly gave people insight into the motivations behind the best, the finest deeds of great men for their nation. $^{37}$

A second virtue of a portrait as history (copy or original) was that it permitted the insertion into an exhibition of one or more themes or topics associated with a particular sitter. ${ }^{38}$ Wentworth's portrait was not found in the Reception Room - rather the gallery appears to have presented the context for his work. The major theme which emerges from the paintings at first appears to be government. The largest group consisted of men associated with the system of government operating in the colony and the subsequent state of New South Wales (not the nation) from the time of Wentworth onwards. Governors, beginning with Lachlan Macquarie, were represented. Although the exhibits were intended as knowledge about historic citizens, the portraits also proposed Wentworth and his colleagues as models, inspiring viewers to engage with the civic duty of the political leaders, aiming to encourage social improvement. ${ }^{39}$ By 1933 a portrait of the State Governor Sir Walter Davison, who took an active interest in preserving Vaucluse House, was inserted, confirming the Trustees' belief in the continuing relevance of the current governmental hierarchies.

Leaders of elected governments, such as Sir John Robertson and Henry Parkes, in power during Wentworth's long incumbency in parliament, were represented. Indeed a second portrait of Parkes, who was well known for his support for Federation, introduced the national theme. In this way the engagement of Wentworth and his colleagues with their civic duty for the old colony of New South Wales strengthened the idea of the continuity of the system, an important point in the early decades of the twentieth century, when socialism and communism were felt to be threatening alternatives.

Portraits of three latter-day Nationalist state politicians were also hung: J. H. Carruthers, W. A. Holman - both Premiers during the 
period when Vaucluse had been acquired by the State or when the museum was put in place - and W. E. Wearne, the then Minister for Lands. Their inclusion alongside historic images made a political statement of unity and continuity, proposing to visitors that those associated in the twentieth century with the conservative coalition were the natural rulers of the state, the legitimate heirs of the mantle of leadership from the past. ${ }^{40}$ Labor Premiers who had also supported the museum when in office were ignored.

The founders of University of Sydney, Charles Nicholson and Roger Therry, who served with Wentworth on the first University Senate, represented a second major theme: education. This was a key sector in nation formation. Sir Henry Parkes portrait, with others who valued educational institutions, reminded visitors of his contribution, championing free, secular and compulsory education. Parkes, however, had also fought for Federation - the formation of the nation. His vision of an industrial nation, whose workforce was educated to operate in modern, industrial times, may have resonated with some visitors. Wentworth and his colleagues who served on the University Senate were admired for their involvement in intellectual work, which prepared them for leadership and marked them off from those who worked manually. It identified them as men who had made their way in the world as successful individuals through their own merits, rather than from the standing of their family. ${ }^{41}$

Meritocratic social advancement was much admired by progressives, such as the self-made men of the VPT.

Richard Jones, on the other hand, identified as a board member with Wentworth on the Bank of New South Wales, and John Macarthur, identified as the 'Wool King', ${ }^{42}$ were men who, while they offered the Trustees the opportunity to make visible the themes of banking and pastoralism (in which Wentworth had engaged), represented successful individuals who had also risen by their own efforts. Their commercial success had long been a national priority, emerging from exploration and settlement and, in its turn, underpinning other forms of progress. ${ }^{43}$

No women were pictured in this space, although women had been prominent in lobbying for universal suffrage and they were making their presence felt in the conscription referenda. With the onset of World War I, bourgeois gender roles, which had begun to be challenged, were reasserted. Middle-class mythologies of gender reemerged to support the dichotomy of the sexes and the associated 
stereotypes of active dominant independent man and passive dependent wives and mothers. ${ }^{44}$

Far from delivering the objective, scientific data guaranteed by 'scientific' history, the portraits of the first exhibit represent a partisan selection - that is, those whom the Trustees and the RAHS instinctively felt were the ruling class of New South Wales. Indeed men of white race, supporting elite class interests, of conservative political persuasion and favouring the official, empire-based national identity were, for the instigators of the Vaucluse House museum, the true representatives of the public life of the nation.

\section{ENTERING THE HOUSE MuSEUM}

At the entrance to the Drawing Room, visitors were reminded by the guide that they were inside the Wentworths' private home. Although thematic exhibits would re-appear in the last two rooms, from this point visitors were located in the house museum. In 1920 and 1921 the Trustees began to steadily install a number of Wentworthprovenanced artefacts at Vaucluse. By 1927, the fabric of the house, too, had been refurbished. The interior fabric was restored and repainted on the advice of newly-arrived specialist Professor Leslie Wilkinson, with the Government Architect overseeing the restoration. ${ }^{45}$ The Trustees now furnished the interior as an old home, with Wentworth-provenanced furniture and effects wherever possible. The display of artefacts in the drawing room was impressive. Two huge, porcelain, Marcolini-period, Meissen vases must have been awe-inspiring. On show by 1932 were other paintings and objects d'art which had also been collected by the family on their visits to Europe, including two very fine Italian pietra dura mosaic tables purchased in Italy by Sarah in the late 1850 s. $^{46}$

The Trustees installed objects 'of the period' to fully furnish the Vaucluse House drawing room and other rooms. ${ }^{47}$ During the $1930 \mathrm{~s}$ depression, a great many such antiques and historic objects came onto the market or were offered to the museum and many were acquired. That the Trust felt justified in importing into an historic site artefacts from other sites and places, illustrates Stephen Bann's point that one aspiration of modernist historical projects was the reconstitution of fragmented shards of evidence from the past into a seamless unified whole. ${ }^{48}$ The house was evidently to be the domestic version of the 'Australian History and Ideal'. 
To be able to reconstitute Wentworth's home into a seamless, ideal, whole, it was even necessary to interpret the spaces of the building using a miscellany of Wentworth artefacts. When the Wentworths had left to go abroad in 1853, they planned to stay away for years, perhaps permanently. A great deal of their furniture and effects were sold at auction. ${ }^{49}$ On their return, new furnishings and possessions, and some pieces from abroad, were installed in the house. Even the reinstated Wentworth objects, therefore, may not all have been from the same period. Certainly some pieces had never been together in the house during the nineteenth century. Their Wentworth provenance and their ability to provide an idealised picture of the activities and the domestic life of a leader of the nation for historical display were the important considerations. This modernist approach favours a visual completeness over other considerations, and, as today's house publications show, remains a compelling consideration. ${ }^{50}$

However, something vital was missing from the commentary and the displays of the drawing room. Images of William were ubiquitous throughout the house. Visitors, however, might have expected to also see the portrait of Wentworth's wife Sarah. But representations of her were for some years absent from the public rooms. In their lifetime, however, the Wentworths' had been shunned by elite New South Wales society and their hopes of social acceptance were never realised. ${ }^{51}$

Sarah, like William, was of convict stock. William had redeemed himself by his public works: his convict origins were not mentioned in the museum tour or displays, nor in Cramp's biography. Sarah's parents had both re-offended once transported to Australia. ${ }^{52}$ This identified her as irredeemably tainted by convict blood. In the first part of the twentieth century the convict stain was still felt to be very shameful. The majority of RAHS historians, persuaded by race theory that these disgraceful tendencies might be inherited, felt the subject reflected badly on Australian history, depriving the national narrative of its moral force. As if this was not enough, Sarah was 'a fallen woman'. The couple's three eldest children were born out of wedlock. ${ }^{53}$ These mores, which also proposed the home as a moral sphere, remained in force, especially in conservative circles, until the 1950s. From the late twenties, the museum owned several representations of Sarah, but at first these were either not displayed for visitors to see or they were placed in obscure corners of the 
museum. Portraits of the illegitimate Thomasine, Willie and Fanny were absent. Individual portraits of the younger children,

Fitzwilliam, Eleanor and Edith, were displayed as well as a group portrait depicting Eliza, Laura and again Edith. Sarah and also her eldest children clearly upset the realisation of the Trustees' vision, permitting only partial groupings of the family and preventing a unified representation of the Wentworths as the ideal Australian bourgeois family.

The Attendant introduced the Marble Dining Room next, drawing attention to the onyx fireplace and mantelpiece and the 'Pompeii floor tiles' adding a sense of luxury and classical cachet. An aristocratic provenance ('from the court of Louis $\mathrm{XV}^{\prime}$ ) was implied for the Wentworth dining furniture placed there, elevating the Wentworths to the status of an 'eternal aristocracy' ${ }^{54}$ Morality, too, was suggested by the tour's identification of the religious content of paintings previously hung there. Despite the rhetoric, the dining room furnishings were incomplete, and included several impressive sideboards not connected with the Wentworths. For some years this room was a neat jumble of grand pieces.

Visitors, whose family stories or education had prepared them, may have understood the agendas and themes which underpinned this display. For others these grand rooms must have been simply confusing or frustrating. The large number of luxury objects appears to communicate overwhelmingly that the Wentworths were very rich. Indeed, without contextualising information this may have been the major lesson available even with a totally authentic original reinstatement. Although the argument at the time was that fine objects encouraged moral distinction, even then there was some disbelief about this claim. ${ }^{55}$ The civilising role of fine objects has similarly been questioned more recently: period rooms are argued to actually foster social rather than moral distinction and to encourage the market for furnishing in antique or in country style. ${ }^{56}$

The so-called 'Ladies Morning Room' across the lobby was next. This cosy little sitting room was decorated and furnished with Wentworth furniture and pieces 'of the period' and free of mainstream masculine historical lessons. This female domain was the sole space in which a complete house-museum re-creation of a Victorian room was achieved. By 1933 a photograph of Sarah was exhibited in this small side-room, alongside some English views. 
Visitors then crossed the Long Hall and the courtyard and were conducted towards a large room at the back known as the Family Dining Room. Here the thematic lessons re-emerged through pictures, though still in the house museum setting of the Wentworth's everyday dining furniture. Eight portraits of Queen Victoria and of Prince Albert hung in this room by 1928. For empire loyalists, such as the Trustees, these were essential representations of leadership and international affiliation. Housed together in this family area, they made a strong visual statement resonating with the well-known metaphor of the monarch as the head of the great family of the British Empire. By gathering these portraits here, rather than scattering them throughout the house, the Trustees struck a delicate balance, simultaneously permitting a greater focus and exploration of Australian local history throughout the museum, while not neglecting to insert its close relationship to the Empire.

Primed by the Royal images to expect more prestigious material, visitors then entered the high point of the tour, the Study or 'Library'. The Trustees took up the RAHS' argument that the room marked as a study on a 1910 Plan must have been Wentworth's library and that he must have drafted the Constitution in this very room. Ignoring advice from the Mitchell Librarian that this could not be substantiated, ${ }^{57}$ they named it the 'Constitution Room.'

The exhibits in this hallowed space made visible the constitutional theme. Here were displayed artefacts associated with the history of the first Constitution of New South Wales and Wentworth's part in its genesis. Portraits of the men who had been with Wentworth in Parliament and on the university Senate were hung by 1927 alongside an oil of 'The First Cabinet under Constitutional Government' and legal and constitutional documents and objects. ${ }^{58}$ The Guide expounded on Responsible Government, the Constitution Bill and their importance for the nation, his script a paean to the founders, especially Wentworth. Visitors were meant to absorb the public spirit of Wentworth and his colleagues and to understand them as national heroes, an inspiration to civic duty and a model of ideal citizenship. For the Trustees, this was the high point and conclusion of the earliest tours for the tour script ended here. 


\section{THE ZENITH ACHIEVED?}

Unforeseen factors, however, soon undermined this tour path and concept. Even in the early years, visitors asked to see the cavernous old kitchen and the cellars. ${ }^{59}$ Moreover, from 1928, after the elimination of white ants made the upper floors safe, three bedrooms upstairs were redecorated and then furnished. As a domestic space of some note the museum was bound to attract women, as it had from the beginning. The newly decorated rooms must have had an effect on the tour, altering its pathway and therefore its focus.

A visit in 1933 by Dorothy Wentworth, who was born in 1873 just after WC Wentworth, her grandfather, died and who remembered the house as a young person, confounded the Trustees' vision. She apparently revealed that the Wentworths had not entered the house from the door off the front verandah at all, but had used a door onto the courtyard, at the side and back, very close to Wentworth's study. The Inventory of 1933 shows that from this time onwards, the artefacts were listed from this door, implying that this obscure, side entrance was now considered the front of the house and that visitors now appear to have begun their tour here. ${ }^{60}$ No longer could a tour be constructed from the Reception Room, through the house treading in the footsteps of the Great Man. Neither did people all walk together along a ritual path from the outside towards the high point, the sacred centre. The impact of the Reception Room portrait gallery and of the Constitution Room would have been seriously diminished. If some self-guided tours were allowed, as the evidence below suggests, there would be no compulsion to visit these out-of- the-way rooms at all. The site still attracted the language of the sacred, but Vaucluse's national significance must have been far less visible. Now people paused and gazed in awe before the antique furniture, furnishings and portraits in the many rooms of a grand old house whose previously salient lessons of conservative, masculine leadership and British- based national identity were becoming obscured. An essential element of the Trustees curatorial plan for visitors was greatly diminished.

Museum equipment also intruded into a museum conceived of as the home of a Victorian gentleman. Some donors expressed concern about the possibility of theft or damage of their objects, leading to the introduction, over time, of seven showcases. ${ }^{61}$ Then, in 1928 a statue of Romeo and Juliet, one of several artworks loaned by the Art 
Gallery of New South Wales was broken, either by a visitor who had not understood either the implicit liberal - or the explicit more authoritarian - lessons of self control in the museum, or perhaps by the sheer crush of visitors. Between 1929 and 1930, moveable wooden barriers were placed in the drawing room and the collection situated around the walls behind them. ${ }^{62}$ The installation of barricades and the large number of visitors also suggest that self-guided tours must have been allowed at times. Such equipment tends to set objects apart, drawing greater attention to their precious qualities, enshrining them. Simultaneously the intrusion mitigates against the house museum experience and emphasises objects of monetary value over historical value. By 1933 the drawing room had taken the form of a fine and decorative arts museum, overcome by that civilising element implicit in the Louvre.

Other considerations, too, confounded the Trust's plans. The policy for re-instatement of the house had been contradictory from the beginning. William Charles Wentworth's life had encompassed activities represented by important themes of Australian history at the time - exploration, pastoralism, government. The Trust accepted many domestic artefacts associated with these themes, including those associated with other figures from Australian history. As the Trust acquired more and more artefacts in the absence of a detailed acquisitions policy, new themes and figures intruded expanding the range of the museum impossibly. Large copies in oils of heroic paintings depicting the exploits of Captain Cook and Burke and Wills were loaned. And artefacts such as Sir Henry Parkes' teapot and explorer William Lawson's sideboard were accepted, here combining domestic and historic themes. An Aboriginal axe was displayed in the same room as a small group of British military weapons and regalia. This telling juxtaposition paradoxically appeared to confirm the military basis of Aboriginal dispossession and to undermine the myth of the time that Australia's tribal people had just faded away. The brief, antiquarian labels, lacking any reference to historical context, gave no assistance in untangling this complex mixture of themes.

The Trustees' strategy was confusing at several levels. It mixed artefacts associated with different historical themes. It also involved two different types of museum presentation. Both have historical value, but they are connected to audiences quite differently. Thematic displays gain their value from their attachment to a cognitive realm - 
a body of historical knowledge. House museums also have historical value, but it emerges from their capacity to offer of an historical experience to visitors. Much of the appeal of house museums remains based on affect and on their historicity - on the sensual and perceptual pleasures of 'being in history.' By and large this is an embodied, localised impact. The house museum experience sharpened the tensions between the two approaches and probably always tended to diminish, in the minds of many visitors, the Trustees' 'national' theme.

Changes in the wider world outside the museum also had their impact. World War I and the 1930s depression produced a profound loss of faith in the idea of great leaders. Public monuments increasingly depicted ordinary people rather than prominent men. ${ }^{63}$ Museums felt the effects of these broader shifts, compounding Vaucluse House's technical problems. New practices and influences appeared at the museum, derived from a new modernist sensibility and a desire for their technical possibilities and / or their modern, upto date more visual sensibility. In 1931 at the height of the Depression, the old formal, oration-centred Wentworth Celebrations were abandoned in favour of a radio broadcast about Wentworth to save money. ${ }^{64}$ Displays of colonial clothing belonging to the Wentworths and other colonial families were exhibited in the butler's pantry. In 1932 the opening of the Harbour Bridge included motorised historical processions and an historical pageant. ${ }^{65}$ Vaucluse House celebrated the historic occasion by organising a pageant of its own. The descendants of historical men and women including but not restricted to the Wentworths, donned the costumes of their ancestors to perform historical roles for visitors. Pages of photographs of these eye-pleasing events filled the press. ${ }^{66}$ Filmmakers arranged photo-shoots of actors in period costume posing at Vaucluse House, perhaps to be shown on the newsreels. ${ }^{67}$

Although visual modes of engagement had always been integral to visitors' experience of the museum, an emphasis on the 'look' of things emerged through an increasing consumer culture. ${ }^{68}$ This increased at the museum as elsewhere, focussing attention on the old interior and its household furnishings. In 1933 the new edition of Karl Cramp's biography of Wentworth included several photographs of the refurbished interior of the house. In 1935 the Trustees discussed obtaining a new pamphlet about the house, for tourists. ${ }^{69}$ It is clear 
that visitors were becoming interested in a more modern, visual emphasis - the look of the past - and in the leisure-based experience of 'being in history' in an old house, rather than absorbing educational facts about responsible government and genuflecting before the heroes of the nation.

Elitist elements remained prominent in the new-style celebrations, with the plum roles at Vaucluse often reserved for contemporary Wentworths and other families with historic connections. The new turn to historicity was part of the emergence of a more communal form of celebration of the nation as smaller local organisations also held their own pageants and costume balls, some at Vaucluse House. ${ }^{70}$ In a tide of history-making encouraged by the opening of the Harbour Bridge in 1932 and the 1938 sesquicentenary celebrations, the old masculinist orations were abandoned as a form of commemoration and people flocked to both participate in and to watch pageants, costume balls, parades, and lawn scenes depicting historical figures and groups. Although the great individual still had a place, the presence of women as historical figures and the possibility of the participation of ordinary people in these events made them, in general, more democratic, as well as more visuallybased, forms of history-making. ${ }^{71}$

By the late 1930s, encouraged by a vibrant and growing manufacturing sector and sense of industrial ascendency in Australia, a new egalitarian and collectivist national culture and identity, similar to that of the 1890s, was emerging to challenge the old Britishbased forms. This time it was associated, however, with a sense of maturity and some identification with American culture. Literary intellectuals writing in Meanjin and Overland made ordinary Australians the focus of their cultural efforts. Young historians such as Brian Fitzgerald, and after the war, Robin Gollan, Ian Turner and Russell Ward all created radical nationalist histories, the latter three working at universities. ${ }^{72}$ In this way, Australian history entered academia along with labour history, a new approach to historiography. History organizations such as the RAHS lost their position of intellectual authority and dominance over the topic of Australian history.

It is difficult now that Vaucluse House has been rigorously reinterpreted as a house museum with a more local emphasis, to recapture the claims of national significance, the centrality of the Constitution Room and the emphasis on constitutional history in the 
museum's foundational period. But it was visited by many school children as well as local and international dignitaries and tourists and even youth groups from as far away as Western Australia. The international Carnegie Foundation's survey of 1933 recognized Vaucluse House as the only museum in Australia devoted entirely to history. ${ }^{73}$ That said, the Vaucluse Trustees had clearly not recognised the internal contradictions within their aims of lionising Wentworth and his work, while simultaneously creating a broad museum of Australian history. Nor had they recognised the limitations of the house museum for the 'national' theme.

The monumental sense of public memory, under quiet challenge since the disillusions of World War I, had lost ground in Australia as elsewhere. In the absence of curatorial authority based on a compelling theme to replace the old empire nationalism, the museum floundered. By the 1950s reports in the press revealed that it was experiencing difficulties. Indeed it was dirty and neglected. ${ }^{74}$ Partly through curatorial inexperience and partly driven by new audience preferences in a changing context, the early tour and its meaning had been undermined and the focus of visitors had unobtrusively shifted from the national history propounded by the Trustees, towards a more visual experience of the museum as an ample, gracious, old middle-class family home furnished with some fine things, but mostly with good but not unduly lavish, nineteenth-century antique furniture. ${ }^{75}$ In the mid 1950s, the house museum was belatedly endorsed as the major approach by a newer, younger cohort of Trustees who moved to dismantle the old thematic exhibition relating to Wentworth and to 'keep the House as a Period House. ${ }^{76}$ The end of the first curatorial period at Vaucluse House had come.

\section{ENDNOTES}

${ }^{1}$ Joanne Pomfrett, 'New Reflections on an Old House,' Public History Review, vol 3, 1994, pp148-166; Charlotte Smith, 'William Charles Wentworth at Vaucluse House: The Effect of Changing Historiography Upon Interpretation,' Public History Review, vol 11, 2004, pp161-176.

${ }^{2}$ NSW Government Gazette 112, 1911, p 4614.

${ }^{3}$ Vaucluse Park Trust Minutes (hereafter VPT Minutes), 20 October 1911, Vaucluse House Archives, Sydney (hereafter VHA).

${ }^{4}$ This Society was soon to gain its 'Royal' prefix, hence the 'RAHS' acronym.

${ }^{5}$ Richard White, Inventing Australia: Images and Identity 1688-1980, Allen and Unwin, Sydney, 1981, p149.

${ }^{6}$ ibid, pp111-112. 
K. R. Cramp, 'Australia: A Greater Britain in a Southern World' Journal of the Royal Australian Historical Society, vol 14, no 6, 1928, pp301-321.

${ }^{7}$ Benedict Anderson, Imagined Communities: Reflections on the Origin and Spread of Nationalism, Verso, New York, 1991, pp178-185.

${ }^{8}$ Minutes, Vaucluse Park Trust (hereafter VPT Minutes), April-July 1918 and April and November 1919, VPT Minute Books, Vaucluse House Archives Sydney (hereafter VHA).

${ }^{9}$ George G. Iggers, Historiography in the Twentieth Century: from Scientific objectivity to the Postmodern Challenge, Wesleyan University Press of New England, Hanover and London, 1997, chapters 1 and 2; K.R. Cramp, Sydney Morning Herald, 2 March 1922, letter to editor pasted into RAHS Minutes, Series 1.8.5, RAHS Archives.

${ }^{10}$ Brian Fletcher, Australian History in NSW: 1888 to 1938, UNSW Press, Sydney, 1993, pp45-46.

${ }^{11}$ VPT Minutes, 26 August 1921.

${ }^{12}$ For example, Karl Cramp, Australian Winners of the Victoria Cross in the Great War 1914-1919, RAHS, Sydney, 1919.

${ }^{13}$ White, op cit, pp85-88; Stuart Macintyre, The Oxford History of Australia Volume 4: The Succeeding Age, 1901-1942 Oxford University Press, Oxford and Melbourne, 1993, pp168-197.

${ }^{14}$ K.R. Cramp, William Charles Wentworth: Explorer, Scholar Statesman, Third Edition, RAHS, Sydney, 1923, p32.

${ }^{15}$ VPT Minutes, 3 October 1919, 26 June 1915, 1 April 1927 and 10 August 1928.

${ }^{16}$ NSW Government Gazette, Sydney, 1911, no 112, p4614.

VPT Minutes, 20 October 1911.

${ }^{17}$ William Welch, 'Vaucluse House,' Sydney Morning Herald, 1 December 1913, p6.

${ }^{18}$ Susan McClean, "'Whither History?": The Emergence of a Modern Preservation Movement in New South Wales', PhD thesis, University of Technology, Sydney, 2007, p171.

${ }^{19}$ Carol Duncan and Alan Wallach, 'The Universal Survey Museum,' Art History, vol 3, no 4, 1980, pp448-469.

${ }^{20}$ Vaucluse House Tour Guide Script (hereafter 'Tour Script'1918-1928), Nielsen-Vaucluse Park Records, File 12, VHA.

${ }^{21}$ Eilean Hooper-Greenhill, Museums and the Shaping of Knowledge, Routledge, London and New York, 1992.

${ }^{22}$ ibid, pp167-190.

${ }^{23}$ VPT Minutes, 28 May1915 and 26 August 1921.

${ }^{24}$ VPT Minutes, 27 July 1917.

${ }^{25}$ Ian Hoskins, 'Reclaiming the City: Spatial Regulation and Definition in the 1909 Royal Commission for the Improvement of Sydney and Its Suburbs', Proceedings of the Planning History Conference, 13 March 1993, University of NSW, Sydney, 1993, p252.

${ }^{26}$ Tony Bennett, The Birth of the Museum: History, Theory, Politics, Routledge, London, 1995, pp37-39.

${ }^{27}$ VPT Minutes, 28 September1917 and 2 July 1926.

${ }^{28}$ VPT Report on Visitor Numbers, op cit.

${ }^{29}$ Eilean Hooper-Greenhill, Museums and the Interpretation of Visual Culture, Routlege, London, 2000, p129.

${ }^{30}$ Tour Script, op cit. 
${ }^{31}$ Bennett, op cit, pp25-32.

${ }^{32}$ VPT Minutes, 5 March 1926.

${ }^{33}$ Hooper-Greenhill, Museums and... Visual Culture, pp5-6.

${ }^{34}$ VPT Minutes, 5 March1926 and 2 July 1926; Tour Script, op cit.

${ }^{35}$ Labelled 'Hall' in the drawing but actually recognized by the Trustees (and by later interpreters) as the Wentworth's formal dining room.

${ }^{36}$ VPT Inventory 1927, Correspondence File 7, VHA.

${ }^{37}$ Hooper-Greenhill, Museums and... Visual Culture, pp38-39.

${ }^{38}$ ibid, p40.

${ }^{39}$ ibid, pp25-26; 31-32.

${ }^{40}$ ibid, pp23-28.

${ }^{41}$ ibid.

${ }^{42}$ List of Pictures Requiring Printed Labels, William Molyneux, 2 November 1926, Correspondence File 3A, VHA.

${ }^{43}$ Hooper-Greenhill, Museums and... Visual Culture, pp31-33.

${ }^{44}$ Carmel Shute, 'Heroines and Heroes: Sexual Mythology in Australia, 1914-1918', in Joy Damousi and Marilyn Lake (eds), Gender and War: Australians at War in the Twentieth Century, Cambridge University Press, Cambridge, 1995, p23.

${ }^{45}$ Government Architect, Plan of Vaucluse House (copy), Neilsen-Vaucluse Park Records, VHA; VPT Minutes, 18 November 1921; Papers re Restoration of Vaucluse House 1922-1924; Correspondence File 8A, VHA. ${ }^{46}$ VPT Inventories and Partial Inventories, 1932-1933, Correspondence File 7, VHA; Carol Liston, Sarah Wentworth, Mistress of Vaucluse, Historic Houses Trust of NSW, Sydney, 1988, p73.

${ }^{47}$ VPT Minutes, 26 August 1921.

${ }^{48}$ Stephen Bann, The Clothing of Clio: A Study of the Representation of History in Nineteenth Century Britain and France, Cambridge University Press, Cambridge, 1986, chapter 1.

${ }^{49}$ Liston, op cit, p59.

${ }^{50}$ Michael Bogle, Vaucluse House, Historic Houses Trust of NSW, Sydney, 1993, p48; Robert Griffin and Joy Hughes (eds), Vaucluse House, a History and Guide, Historic Houses Trust of NSW, Sydney, 2006.

${ }^{51}$ ibid, pp41-60.

52 ibid, pp7-12.

53 ibid, pp13-22.

${ }^{54}$ Carol Duncan, 'The Art Museum as Ritual', Art Bulletin, vol 77, no 1, 1995, p2.

${ }^{55}$ Graeme Davison, 'Exhibitions', Australian Cultural History, vol 2, 1982, p10.

${ }^{56}$ Kylie Winkworth, 'Country Style, the Market and the Museum', Australian Historical Studies, vol 24, no 96, 1991, pp117-129.

${ }^{57}$ W.H. Iffould, Notes on Vaucluse House compiled in Response to request for information from Vaucluse Park Trustees, April 1913, VHA, p11.

${ }^{58}$ VPT Inventory (1927) and Inventory, 20.03.1932, Correspondence File 7, VHA.

${ }^{59}$ VPT Minutes, 2 July 1926.

${ }^{60}$ VPT Minutes, 23 March 1933; see also Subsidiary Inventory, 1933, Correspondence File 7, VHA.

${ }^{61}$ For example, VPT Minutes, 14 February 1926.

${ }^{62}$ VPT Minutes, 7 January 1927; VPT receipt, Oct 1927, for table, rail and other items, Correspondence File 8A. 
${ }^{63}$ Graeme Davison, The Use and Abuse of Australian History, Allen and Unwin, Sydney, 2000, pp36-55.

${ }^{64}$ VPT Minutes, 18 June1932.

${ }^{65}$ Sydney Harbour Bridge Official Souvenir (transcript) in Terry Eakin, 'Lane Cove and the Sydney Harbour Bridge Opening', Lane Cove Historical Society Newsletter, no 212, 2006, p3.

${ }^{66}$ Two prominent examples were the Harbour Bridge celebrations and the 1938 Sesquicentenary of settlement celebrations; 'The Historical Pageant at Vaucluse House', Sydney Mail, 23 March 1932, p28; VPT Minutes, 9 December 1936 and 21 June 1938.

${ }^{67}$ Cinesound Productions, 'Actors at Vaucluse House', 1932, Hood Collection, Home and Away, 25896, Mitchell Library, Sydney.

${ }^{68}$ McClean, op cit, pp82-87.

${ }^{69}$ VPT Minutes, 18 September 1935.

${ }^{70}$ VPT Minutes, 6 December 1930.

${ }^{71}$ Stephen Gapps, 'Performing the Past: A Cultural History of Historical Reenactments', PhD Thesis, University of Technology, Sydney, 2002, pp180-190.

${ }^{72}$ White, op cit, pp148-154.

${ }^{73}$ H. C. Richards, A Report on the Museums and Art Galleries of Australia and New Zealand, The Museums Association, London, 1933.

${ }^{74}$ 'Shocking Neglect at Vaucluse House', Daily Mirror, 19 April 1955; Alfred J. Schmude, Vaucluse House Scrap Book, Caroline Simpson Library, Historic Houses Trust, Sydney, p22.

${ }^{75}$ Bogle, op cit, p46.

${ }^{76}$ Smith, op cit, p168. 